Volume 6 Issue 4, December 2019

Nationally Accredited Journal,

Decree No. B/4130/E5/E5.2.1/2019

\title{
Effects for Land Deed Official (PPAT) in the Sale and Purchase Agreements of Land Which Does Not Match With Procedure of the Land Deed Making in Magelang
}

\begin{abstract}
Sahudi $^{1}$, Akhmad Khisni ${ }^{2}$ and Achmad Sulchan ${ }^{3}$
Abstract. The purpose of this study was to analyze: 1) The forms of the deed of sale of land that is not in accordance with the procedures of the Land Deed Manufacture in Magelang. 2) The cause of the Deed of Sale and Purchase of Land not in accordance with the procedures of the Land Deed Manufacture in Magelang. 3) The legal consequences for the Land Deed Official (PPAT) in the manufacture of a deed of sale of land that is not in accordance with the procedures show a deed of land in Magelang.

This research is normative juridical approach, the sociological juridical approach. The collection of primary and secondary data obtained by interview and literature study, then analyzed by qualitative analysis method.

The research results are: 1) The forms of the deed of sale of land that is not in accordance with the procedures Making Land Deed in Magelang among which the sales and purchase agreement by the parties do not before PPAT who signed the deed of sale (deposit certificate), signing not done in the same time in front of PPAT, the transaction price values contained in the deed of sale is different from the actual transaction value. 2) The cause of the Deed of Sale and Purchase of Land not in accordance with the procedures Making Land Deed in Magelang, namely the existence of a situation which requires PPAT to manufacture the deed of sale that is not in accordance with the procedures deed PPAT is needed in order to save a sale and purchase transaction, their high trust between the parties with PPAT, a factor the value of security be so PPAT would follow the wishes of the parties. 3) The legal consequences for Deed Official Land (PPAT) in the manufacture of a deed of sale of land that is not in accordance with the procedures show a deed of land in the district of Magelang is PPAT be dishonorably discharged from his position, may be subject to administrative sanctions and fines in accordance with the regulations applicable. Keywords: Sale and Purchase Agreements; PPAT; Effects.
\end{abstract}

\section{Introduction}

The rapid increase in demand for land with the limited supply of land at this time, also have a major impact for the increase in value and the price of land. This increases the potential for conflicts and problems related to or caused by the soil. The increasing complexity of the problems of human life caused by the current land requires that there is a rule governing the legal guarantee in the relationship between man and land. ${ }^{4}$

There were two attempts to create legal certainty of land. First, by providing devices completely and clearly written law. Secondly, by way of the registration of the land

\footnotetext{
${ }^{1}$ Student Master of Notary Program, Faculty of Law, Sultan Agung Islamic University Semarang, Email: sahudimh1@gmail.com

2 Lecturer, Faculty of Law, Sultan Agung Islamic University Semarang

3 Lecturer, Faculty of Law, Sultan Agung Islamic University Semarang

4 Dyara Radhite Oryza Fea, 2018, Panduan Mengurus Tanah Rumah dan Perizinannya, Yogyakarta: Legality, p. 2
} 
which allows for holding the titles to prove rights to the land under its control and for the government to implement land policy. ${ }^{5}$

Land transport legal certainty regarding the ownership and control of land include the following elements:

- Certainty on the subject of rights that person or legal entity that owns the rights.

- Certainty of sports rights regarding the lay of the land, boundaries and spacious plot of land.

In order to achieve this aim, it is in the implementation, the registered rights holders will be given a receipt of rights, to easily prove their rights have been registered. In addition to the National Land Agency (BPN), the parties play an important role in the orderly land is the Land Deed Official. (PPAT). According to article 1, paragraph (1) of Government Regulation No. 24 Of 2016 regarding Amendment to Government Regulation No. 37 Of 1998 concerning Regulation Deed Official Land, PPAT is a public official who is authorized to make the deeds of authentic regarding certain legal actions over land rights or ownership of the apartment units. ${ }^{6}$ Legal act in question is a sale and purchase, exchange, donation, inclusion into the company, the division of joint property, granting building rights, land use rights or property rights, the provision of security rights, and giving the authority to the security rights.

In carrying out its authority, PPAT should avoid things that can give rise to disputes, lest the deed contains the formula that may cause disputes because it is incomplete and unclear. Because the PPAT deed an authentic act which has the absolute strength of evidence on matters or events referred to in the deed, then that is proven is uneventful. In the purchase, the buyer must qualify the subject of land to be bought it. Similarly, the seller, must also qualify is authorized to assign the land. Making the deed of sale of land rights should be attended by the parties concerned to take legal actions and witnessed by at least two witnesses who are qualified to act as a witness in the legal act. ${ }^{7}$ In addition, the deed of sale was to be made by using the forms and procedures that have been determined. Deed of sale of land is a very important thing that works for the transfer of property rights to land and the ownership of land. ${ }^{8}$

The problem of the scarcity of PPAT officials in the countryside and has not been designated or less PPAT While in Magelang resulted in many a deed of sale of land that were made without following the correct procedure, so that it will lead to legal consequences for not complying with the procedures of making the land deed. Based on the above raised the title of "Effects For Land Deed Official (PPAT) Making the Sale and Purchase Agreements In the Land of the Not In accordance with the Procedure of Preparation of Deed Land in Magelang District".

This study sought to answer concerns regarding forms a deed of sale of land that is not in accordance with the procedures Making Land Deed in Magelang District, the causes of the Deed of Sale and Purchase of Land not in accordance with the procedures Making Land Deed in Magelang and legal effect to the Deed Official Land (PPAT) in the making deed of sale of land that is not in accordance with the procedures show a deed of land in Magelang.

\footnotetext{
${ }^{5}$ Ibid, p. 90

${ }^{6}$ Article 1 (1) of Government Regulation No. 24 of 2016 regarding Amendment to Government Regulation No. 37 of 1998 on the Land Deed Official Rules

${ }^{7}$ Adrian Sutedi, 2018, Peralihan Hak Atas Tanah dan Pendaftaranya, Ninth Edition, Jakarta: Sinar Grafika, p. 80

8 Harun al-Rashid, 1987, Sekilas tentang jual Beli Tanah, First Edition, Jakarta: Ghalia Indonesia, p.64
} 
Volume 6 Issue 4, December 2019

Nationally Accredited Journal,

Decree No. B/4130/E5/E5.2.1/2019

\section{Research methods}

The method used in this research is normative juridical approach. Specification The research was analytic descriptive describes the applicable laws and regulations associated with the law theories and practice implementation. ${ }^{9}$ Primary and secondary data sources obtained by interview and review of the literature (study document). The data have been collected either from the research and literature research will be analyzed with descriptive analysis method and qualitative analysis.

\section{Results and Discussion}

\subsection{The forms of the Deed of Sale and Purchase of Land Not accordance with the Procedure for the Deed Land in Magelang}

\subsubsection{Sales and purchase agreement by the parties do not before PPAT who signed} the deed of sale (deposit certificate).

This happens because the object of the right to land is located outside the working area PPAT concerned (PPAT work area is the working area of the District Land Office / municipality, Article 12 of Government Regulation No. 24 of 2016 on the Rules of Land Deed Official Position). PPAT is not authorized to make the deed if the subject matter of land rights lie outside the area of work. This situation occurs in the buying and selling process as follows:

- The parties, the seller and the buyer have agreed to hold the next sale and purchase of the parties agreed to the signing of the deed of sale at the office PPAT. PPAT PPAT chosen is that the area of work is outside the land rights where the object is located. Reasons for the selection of PPAT in question is for the parties or one party, has long been a client of PPAT it, so it's been very confident with PPAT are, therefore even if the object of land rights will be traded situated outside the working area PPAT, the parties or one of the parties still insist to use the services of the PPAT. The process of signing the deed of sale in the case as described above, is before the signing of the deed is done as usual PPAT deed that will leave,

- At the time of signing the deed, blank had been filled with names of PPAT following with witnesses of PPAT whose area of work covers the area in which the object of the land rights are (PPAT to be entrusted deed) and the completed based on the documents and data which have been submitted by the parties. The deed then by PPAT who will entrust the deed read out to the parties and the parties are asked to sign it. After the parties signed the deed, the deed by which he entrusts PPAT deed, along with all supporting data was then submitted to PPAT who will receive the deposit certificate for further processing. ${ }^{10}$

\subsubsection{The signing of the deed of sale by the seller and the buyer is not done at the} same time in front of PPAT

The process of making the deed of sale such as this can occur for various reasons. The main reason is because of the rush of the parties so that the parties can not come to the office PPAT at the same time for the signing of the deed. According to Article 101 Regulation of the Minister of Agriculture / Head of National Land Agency No. 3 of 1997

\footnotetext{
${ }^{9}$ Sumardi Suryabrata, 1993, Metodologi Penelitian, Jakarta: Rajawali, p.19

${ }^{10}$ Interview with Ms. AA, Notary and PPAT in Magelang District, dated 20 September 2019
} 
on the Implementation of Government Regulation No. 24 of 1997 on Land Registration, signing the deed should be done by the parties (seller and buyer) in the presence of PPAT.

\subsubsection{Sale and Purchase Agreements have been signed but the certificate has not} been checked for conformance with the land book at the land office

Article 97 of the Regulation of the Minister of State for Agrarian Affairs / Head of National Land Agency Number 3, 1997 About Conditions Implementation of Government Regulation No. 24 of 1997 on Land Registry stated that, prior to the manufacture of the deed of sale executed PPAT obligation to conduct an examination of certificates are concerned with lists in the local land office. The uncertainty of whether or not the examination time do finally make the parties agree to immediately sign a deed of sale even though the examination can not be done. The signing was done by a blank deed of sale is filled with data that exist but the numbering and date of the deed of sale has not been made.

\subsubsection{Deed was signed outside the office PPAT and without the presence of witnesses.}

The signing of the deed in this case is done by because one of the parties can not come to the office for some reason PPAT by the parties concerned and is a friend or relative of the PPAT. To perform the signing of the deed, PPAT came to the party and asked the parties to sign, which had previously been signed by the other party. So the deed was signed in the presence of PPAT but not attended by the witnesses.

\subsubsection{Transaction price values contained in the deed of sale is different from the actual transaction value.}

In Government Regulation No. 34 Of 2016 regarding Income Tax on Income from Transfer of Land and / or buildings, and the Agreement the Sale and Purchase of Land and / or buildings along its amendment stipulated that the calculation of taxes to be paid by the parties in terms of transfer of rights land is calculated based on the value of transactions on the transfer of rights to the land, if the value of the transaction is unknown. Article 1 set:

- On income derived by the individual or entity from:

- on acquisition of land and / or buildings.

- binding sale and purchase agreement of land and / or building and its amendments, outstanding final Income Tax.

- Income of the transfer of rights to land and / or buildings referred to in paragraph (I) letter $a$ is income be accepted assignor or acquired rights to land and / or buildings by sale, exchange, relinquishment of rights, transfer of rights, auctions, grant, inheritance, or other means agreed between the parties.

- Income from binding sales agreement to buy land and / or buildings and amendments referred to in paragraph (1) letter $b$ is income from:

- the seller who is named in a binding sale and purchase when the first was signed; or

- the buyer named in the binding sale and purchase agreement before a change or amendment of the binding sale and purchase agreement, the buyer upon the occurrence of changes in the binding sale and purchase agreement.

As for determining the amount of the amount to be paid under Article 2: 
Volume 6 Issue 4, December 2019

Nationally Accredited Journal,

Decree No. B/4130/E5/E5.2.1/2019

The amount of income tax on acquisition of land and / or buildings referred to in Article 1 , paragraph (1) letter a is equal to: ${ }^{11}$

- $2.5 \%$ (two point five percent) of the gross value on acquisition of land and / or building other than on acquisition of land and / or buildings in the form of Simple Houses or Flats Simple done by taxpayer whose main business transferred rights land and / or building;

- $1 \%$ (one percent) of the gross value on acquisition of land and / or buildings such as Simple House and Flats Simple done by taxpayer whose main business conduct on acquisition of land and / or building; or

- $0 \%$ (zero percent) on the transfer of rights to land and / or buildings to the government, state-owned enterprises that receive special assignments from the Government, or regionally owned enterprises that receive special assignments from the head area, as defined in the laws that govern bag regarding land acquisition, construction of public interest.

Making the deed of sale that the transaction value right shift is smaller than the real deal is done to reduce the amount of tax payment obligations BPHTB and PPH. Usually the value of the transactions contained in the deed of sale is the value of taxable value (NJOP) rounded upward, so that the taxes to be paid is based on the value SVTO rounded upwards. So the purpose of perpetration of the transaction value diminution in the deed of sale is to understate the amount of taxes to be paid. Usually before a transaction carried out by the parties beforehand created the SPA (Sale and Purchase Agreement) by PPAT in his post as a Notary Public. ${ }^{12}$

\subsection{Causes of the Deed of Sale and Purchase of Land Not accordance with the Procedure for the Deed Land in Magelang}

Factors that cause the deed of sale of land not in accordance with the procedures of making a land deed in Magelang District, among others:

- There is a mutual trust is very high among PPAT and between the parties with PPAT, a kind of "esprit de corps", so they believe that among PPAT will protect and will not open the secrets that exist between them and between them there are also mutual understanding and mutual understanding. This has led to the belief among them that their actions will be safe and there will be problems later on which may make it difficult for them. Things like this seem in terms of construction and selling by way of deposit certificates. PPAT who left entirely to the PPAT deed of trust which receives deposits, which receives deposits that PPAT deed would do good service to which he entrusts PPAT deed and to clients who entrust PPAT deed and vice versa.

- The existence of a situation which requires PPAT to manufacture the deed of sale that does not comply with the procedures PPAT deed, which is needed in order to save a sale and purchase transaction. Making the deed of sale as it looks in the form of purchase and sale transactions where the taxes owed and the unpaid purchase price has not been paid in full upon signing the deed is done.

\footnotetext{
${ }^{11}$ Article 2 of Government Regulation No. 34 of 2016 regarding Income Tax on Income from Transfer of Land and / or buildings, and the Sale and Purchase Agreement on Land and / or buildings along its amendment.

12 ibid
} 
- The time factor and bustle of the party causing the PPAT adjust to time and bustle of the parties. Such a situation is seen in the construction of purchase in respect of which the signing of the deed of sale do not in the presence of the parties and not simultaneously. Deed of sale was signed first by one side and after that one of the other parties to sign the deed of sale.

- Factors relationships and friendships can also be a reason for PPAT fatherly conduct the sale and purchase deed which is not in accordance with the procedure PPAT deed. This is done by PPAT in order to maintain good relations with relatives or friends, because when PPAT in question does not want to fulfill the wishes of relatives or friends, then relatives or friends will feel treated equally with clients PPAT others and feel they are not get preferential or special treatment. Such conditions occur in construction and selling where signatories deed done by one of the parties by way of PPAT concerned who come to the party in the absence of a valid reason and justified.

- Factors that caused by the demands of the parties. The desire of the parties to ask PPAT to manufacture the deed of sale which resulted in the loss of the state in terms of tax revenue. Incidents like this seen in construction and selling in terms of transaction value in the deed of sale is lower than the actual transaction value. ${ }^{13}$

From various factors and reasons as mentioned above, there is the possibility of a combination of several factors and reasons in terms of making the deed of sale that is not in accordance with the procedures PPAT deed. So there is the possibility of buying or selling, manufacturing carried out by one or more ways that are not in accordance with the procedure PPAT deed.

\subsection{Effects For Land Deed Official (PPAT) in the Sale and Purchase Agreements Soil Preparation Not accordance with the Procedure of Preparation of Deed Land in Magelang}

In the making of the deed of sale that is not in accordance with the procedures, it will cause legal consequences for PPAT deed of sale as well as for the legal consequences arising are:

- In cases such as the signing of the deed of sale which do not before PPAT (deposit certificate) legal consequences for PPAT is able dishonorably discharged from office as provided for in Article 10 paragraph (3) letter (a) of Government Regulation No. 24 Of 2016 About the Position Rules Land Deed official: that PPAT can be dishonorably discharged from office by the Head of the Agency, for committing grave violations of prohibitions or obligations as PPAT.

- The signing of the deed of sale which do not before PPAT legal consequences for the deed of sale made is proof strength becomes degraded deed under the hand because it does not meet the requirements specified by law or other regulations.

- The legal consequences of signing the deed of sale by the seller and the buyer is not done at the same time in front of PPAT, for PPAT makes is may be subject to administrative sanctions and penalties (Article 62 of the Indonesian Government Regulation No. 24 of 1997 on Land Registration PPAT deep his duties prejudice to the provisions referred to in Article 38, Article 39 and Article 40 as well as the rules and instructions given by the Minister or authorized officials imposed administrative measures in the form of a written warning to dismissal from his post as PPAT,

\footnotetext{
${ }^{13}$ Interview with Mr. S, Notary and PPAT in Magelang District, dated 20 September 2019
} 
Volume 6 Issue 4, December 2019

Nationally Accredited Journal,

Decree No. B/4130/E5/E5.2.1/2019

without prejudice to the possibility sued for damages by parties who suffered losses caused by the neglect of these provisions.

- Deed signed outside the office PPAT and without the presence of witnesses, the legal consequences are in addition to administrative sanctions or fines administrative action PPAT can also be written reprimand to dismissal from his post as PPAT, without prejudice to the possibility of compensation demanded by the parties- those who suffered losses caused by the neglect of these provisions.

- The legal consequences other is that if there are problems with the deed of sale of that or found unlawful, the parties or third parties concerned can take advantage of this situation, suppose that the third party will file a lawsuit but the knock by their authentic act which has the strength of evidence that is perfect (only one is enough evidence as the basis for a case breaker).

\section{Closing}

\subsection{Conclusion}

- The forms of the deed of sale of land that is not in accordance with the procedures Making Land Deed in Magelang among which the sales and purchase agreement by the parties do not before PPAT who signed the deed of sale (deposit certificate), the signing of the deed of sale by the seller and the buyer not done in the same time in front of PPAT, deed of sale were signed but the certificate has not been checked for conformance with the land book at the land office, the deed was signed outside the office PPAT and without the presence of witnesses, and the value of the transaction price contained in the deed of sale purchasing different from the actual transaction value.

- Factors causing the Deed of Sale and Purchase of Land not in accordance with the procedures Making Land Deed in Magelang, namely their high trust between the parties with PPAT causing them to entrust entirely deed to PPAT they believe, factors bustle of the parties, resulting in the signing of the deed of sale PPAT is not done before, the length of checking the certificate at the Land Office, a factor the value of security be so PPAT would follow the wishes of the parties, for example in terms of making the deed of sale that are outside the area of work.

- The legal consequences for Deed Official Land (PPAT) in the manufacture of a deed of sale of land that is not in accordance with the procedures show a deed of land in the district of Magelang is PPAT be dishonorably discharged from his position, may be subject to administrative sanctions and penalties in accordance with applicable regulations,

\subsection{Suggestion}

- For PPTA, should be more active PPAT studied law because the legal rules are always changing and may increase. PPAT have to perform tasks in accordance with the provisions of the applicable law, and do not violate the applicable regulations for the proximity to the client.

- To the public, should be more active in the manufacture of the deed of sale, do not entrust everything to PPAT, this is to avoid any disputes or problems in the future. 


\section{References}

[1] Adrian Sutedi, 2018, Peralihan Hak Atas Tanah dan Pendaftaranya, Ninth Edition, Jakarta: Sinar Grafika

[2] Ali Ahmad Chomzah, 2004, Hukum Agraria (Pertanahan Indonesia), Volume 2, Jakarta: Prestasi Pustaka Publisher

[3] Bambang Sunggono 2003, Metodologi Penelitian Hukum, Jakarta: Raja Grafika Persada

[4] Dyara Radhite Oryza Fea, 2018, Panduan Mengurus Tanah Rumah dan Perizinannya, Yogyakarta: Legality

[5] E, Fernando M. Manulang, 2016, Legisme, Legalitas Dan Kepastian Hukum, Edition: I, Kencana.

[6] Habib Adjie, 2008, Sanksi Perdata dan Administratif Terhadap Notaris sebagai Pejabat Publik, Bandung: Refika Aditarna

[7] Harun al-Rashid, 1987, Sekilas tentang Jual Beli Tanah, First Edition, Jakarta: Ghalia Indonesia

[8] Peter Mahmud Marzuki, 2010, Penelitian Hukum, Jakarta: Kencana Prenada Media Group

[9] Salim HS, 2016 Teknik Pembuatan Akta satu, Jakarta: Raja Grafindo Persada

[10] Samun Ismaya, 2001, Pengantar Hukum Agraria, First Edition, Yogyakarta: Graha Ilmu

[11] Soedharyo Soimin 2004, Status Hak \&Pembebasan Tanah, Jakarta: Sinar Grafika

[12] Government Regulation No. 24 of 1997 on Land Registration

[13] Regulation Government No. 20 of 2015 on Land Agency.

[14] Regulation Government Number 24 Of 2016 regarding Amendment to Government Regulation No. 37 of 1998 on the Land Deed Official Rules

[15] Regulation Government Number 34 Of 2016 regarding Income Tax on Income from Transfer of Land and / or buildings, and the Sale and Purchase Agreement on Land and / or buildings along its amendment.

[16] Akmelen Zulda 2010, Effects of Making the Sale and Purchase Agreements Soil Not accordance with the Procedure for the Deed of PPAT, Thesis Diponegoro, Semarang.

[17] Fery Harjanto, Effects of Preparation of Deed of Sale and Purchase of Land Which Does Not Match Procedure for the Deed of Land, Thesis, Magister of Law Unissula, Semarang. 